Marco Ghignone mD FRCPC, Octavio Calvillo MD PH D, Luc Quintin MD PH D, Samuel Caple BS, Raymond Kozody MD FRCPC

\title{
Haemodynamic effects of clonidine injected epidurally in halothane- anaesthetized dogs
}

The haemodynamic effects of clonidine administered in the cpidural space were studied in 16 halothane-anaesthetized dogs. The animals were randomly assigned to two groups: Group I received three doses of 3 ml of normal saline, Group $/ /$ received three doses of $3 \mathrm{\mu g} \cdot \mathrm{kg}^{-1}$ of clonidine, through an epidurai catheter, whose tip was located between $L_{2}-T_{11}$. Control haemodynamic measurements were taken one hour after completion of the surgical preparation (period $P_{3}$ ); they were repeated every 45 minutes after each incremental dose (periods $P_{2}, P_{3}, P_{4}$ ) and 105 minutes after a total cumulative dose of $9 \mu \mathrm{g} \mathrm{kg}^{-1}$ of clonidine or $9 \mathrm{ml}$ of saline were given (periud $P_{5}$ ). No significant changes aver time were observed in Group I. In Group /I cloni. dine produced statistically significant reductions of systemic blood pressure $(B P)$, mean left ventricular pressure $(L V)$, heart rate (HR), cardiac output ( $C O$ ) and peak $L V$ dP/dt only after a total clonidine dose of $9 \mu \mathrm{g} \cdot \mathrm{kg}^{-1}$ and these changes were sus tained. BP fell 15 per cent, $C O 21$ per cent, HR 25 per cent, $L V 20$ per cent and peak $L V d P / d t 30$ per cent when $P_{s}$ measurements were compared to control values within Group II $(p<0.05)$. These haemodynamic effects of clonidine are likely due to minimal systemic absorption andior cephalad spread of the drug towards its site of action in the brain stem. The reductions of $H R, C O, B P$, and isovolemic indices of contractility are likely explained by a reduction of sympathetic outfow at the spinal cord and medulla oblongata levels as well as increased parasympathatic tone.

If ihese observations can be extrapoluted to clinical conditions, in view of the small haemodynamic changes observed only with the highest dose employed, and the potent analgesic effects, epidural administration of clonidine appears safe and may be useful for management of acule postoperative pain

\section{Key words}

EPIDURAL ANALGESIA: clonidine; HAEMODYNAMICS: epidural clonidine; SYMPATHETIC NERVOUS SYSTEM: clonidine.

From the Department of Anaesthesiology, Texas Tech University, Health Sciences Center, Lubbock, Texas, and The Department of Ancsthesia, Univcrsity of Manitoba, Health Sciences Centre, Winnipeg, Manitoba.

Address correspondence to: Dr. M. Ghignone, Department of Anesthesiology, Texas Tech University, Health Sciences Center, 3601 4th Street, Lubbock, Texas 79430.
Clonidine, a centrally acting antihypertensive agent, ${ }^{1}$ has been reported to have significant antinociceptive properties in animals ${ }^{2}$ and in humans. ${ }^{3}$ Coombs et al. ${ }^{4}$ reported that intrathecal clonidine provided effective pain relief in a patient with malignant pain who had developed narcotic tolerance; however, significant hypotension and bradycardia occurred. Calvillo and Ghignone ${ }^{5}$ suggested that clonidine selectively modulates $\mathrm{C}$ fibre input (and therefore nociception) to the spinal cord by presynaptic mechanisms. These studies suggest that the spinal cord mediates the antinociceptive properties of clonidine and, furthermore, that the sympathetic nervous system participates in nociceptive modulation. ${ }^{6}$ This, however, does not rule out the possibility that clonidine also has supraspinal sites of action, as it has been suggested. ${ }^{\text {? }}$

Several studies have reported the effects of clonidine administered intrathecally or epidurally on nociceptive threshold and blood pressure in awake and anaesthetized preparations ${ }^{8-10}$ Intrathecal administration of clonidine in doses ranging from 0.1 to $5 \mu \mathrm{g}$ in rats resulted in a gradual, prolonged and dose-dependent reduction in BP and HR; larger doses caused a predominant hypertensive response, likely due to systemic absorption. ${ }^{8.9}$ By contrast, continuous epidural infusion of very large doses of clonidine (100 to $600 \mu \mathrm{g} \cdot \mathrm{kg}^{-1}$. day ${ }^{-1}$ in chronically instrumented rams) did not produce significant changes in $\mathrm{BP}$ and HR. ${ }^{10}$ The use of epidural clonidine could become widespread in certain subsets of patients if the haemodynamic repercussions were minimal. This study was designed to investigate the full haemodynamic consequences that follow the acute administration of clonidine in the epidural space of the dog.

\section{Methods}

Anaesthesia was induced in 16 mongrel dogs weighing 18 to $24 \mathrm{~kg}$ with thiopentone ( $20 \mathrm{mg} \cdot \mathrm{kg}^{-1}$ ) and maintained with halothane one per cent end-expiratory concentration (Beckman $\mathrm{LB}_{2}$ Halothane analyzer, Beckman Instruments, Fullerton, $\mathrm{CA}$ ) in $\mathrm{O}_{2}$. Mechanical ventilation was instituted with a tidal volume of $20 \mathrm{mg} \cdot \mathrm{kg}^{-1}$ via an endotracheal tube. An epidural catheter was inserted at the $\mathrm{L}_{3}-\mathrm{L}_{4}$ interspace through an 18 gauge Crawford needle. The epidural space was identified by the loss of 
resistance technique; radiographic confirmation of the catheter position was obtained by lateral and posteroanterior projections. The catheter tip was located between $\mathrm{L}_{2}$ and $T_{11}$. A catheter was placed in the thoracic aorta via the internal carotid artery to monitor systemic blood pressure (BP) and to obtain samples of arterial blood. A thermistor-tipped flow-directed catheter was inserted via the external jugular vein and advanced in a branch of the pulmonary artery where pulmonary artery pressure (PA) and pulmonary capillary wedge pressure (PCWP) were obtained. A second thermistor-tipped catheter was positioned in the right atrium for injection of saline boluses for cardiac output (CO) determination. Thermodilution curves were recorded at least four times in each condition and averaged. The per cent standard error of the mean (SEM\%) of the CO measurements averaged four per cent. A catheter-tip manometer (Millar PC 350, Millar Instruments, Houston, TX) was inserted via the femoral artery into the left ventricle (LV) to obtain left ventricular pressure; the signal was differentiated to obtain peak LV $\mathrm{dP} / \mathrm{dt}$.

All vascular pressures were referred to the centre of the chest with the animal in the supine position. The transducers' outputs, the ECG, end-tial halothane concentration and thermodilution curves were displayed on an 8-channel recorder. Heart rate was obtained by a standard limb lead ECG. These preparations were usually completed in about one hour during which time approximately $25 \mathrm{mg} \cdot \mathrm{kg}^{-1}$ of lactated Ringer's solution was infused to adjust the PCWP to approximately $6 \mathrm{mmHg}$; subsequently the infustion rate was set at $50 \mathrm{ml} \cdot \mathrm{hr}^{-1}$. Baseline measurements (pcriod $\mathrm{P}_{1}$ ) of $\mathrm{BP}, \mathrm{CO}, \mathrm{PA}$, PCWP, LV end diastolic pressure (EDP), peak LV dP/dt and $H R$ were recorded after a stabilization period of at least 60 minutes, during a ten-second apnoeic period at functional residual capacity. The animals were then randomly assigned to two groups. Group $l(N=8)$, the control group, received preservative-free normal saline in $3 \mathrm{ml}$ increments through the epidural catheter for a total volume of $9 \mathrm{ml}$; Group II $(\mathrm{N}=8)$, the clonidine group, was administered freshly prepared clonidine solution (Bohringer Ingelheim, Ridgefield, CT) in three doses of $3 \mu \mathrm{g} \cdot \mathrm{kg}^{-1}$ (total dose $9 \mu \mathrm{g} \cdot \mathrm{kg}^{-1}$ ) in the same volume as in Group I. Subsequent measurements were obtained at 45-minute intervals following epidural administration of either clonidine or saline: periods $P_{2}, P_{3}, P_{4}$. Final measurements $\left(P_{5}\right)$ were taken 60 minutes after the last epidural injection. Arterial blood gases were sampled hourly and $\mathrm{pH}$ was maintained between $7.35-7.45$ by administration of sodium bicarbonate or by adjustment of ventilatory rate to maintain $\mathrm{PaCO}_{2}$ between 30 and $40 \mathrm{mmHg}$. Temperature was maintained between 37.5 and $38.5^{\circ} \mathrm{C}$ with a warming blanket. Pulmonary vascular resistance was calculated as PVR $=$ (mean PA-PCWP) $/ \mathrm{CO}$, and system vascular resistance (SVR) as mean BP-right atrial pressure/CO.

Analysis of variance employing the Tukey's method was performed; the Bonferroni inequality correction for the $\mathrm{t}$-test was then applied to the haemodynamic data for selected pairs of simultaneous multiple comparisons. ${ }^{11}$ The differences between control values and values of each of the conditions within and between groups were considered significant when $\mathrm{p}$ was $<0.05$.

\section{Results}

The haemodynamic data of Group II are reported in the Table. Acute epidural administration of clonidine up to a mean dose of $6 \mu \mathrm{g} \cdot \mathrm{kg}^{-1}$ resulted in no significant haemodynamic effects. Significant changes of BP, LV, HR, CO and peak $L V \mathrm{dP} / \mathrm{dt}$ were observed only after a total cumulative dose of $9 \mu \mathrm{g} \cdot \mathrm{kg}^{-1}$ of clonidine $\left(P_{4}\right)$ and were sustained for the period of observation $\left(\mathrm{P}_{5}\right)$

The maximum reduction of $B P$ was 15 per cent when $P_{5}$ was compared with control value $(p<0.05)$. The other

TABLE Haemodynamic effects of clonidine administered epidurally (mean \pm SD)

\begin{tabular}{|c|c|c|c|c|c|}
\hline & $\begin{array}{l}\text { Pi } \\
\text { Control }\end{array}$ & $\begin{array}{l}P_{2} \\
45 \text { min afler } 3 \mu \mathrm{g} \cdot \mathrm{kg}^{-1}\end{array}$ & $\begin{array}{l}P_{S} \\
45 \min \text { after } 6 \mu \mathrm{g} \cdot \mathrm{kg}^{-1}\end{array}$ & $\begin{array}{l}P_{4} \\
45 \text { min affer } 9 \mu g \cdot \mathrm{kg}^{-1}\end{array}$ & $\begin{array}{l}P_{5} \\
60 \text { minaffer } P_{4}\end{array}$ \\
\hline$C O L \cdot \min ^{-1}$ & $1.86 \pm 0.21$ & $1.8 \pm 0.2$ & $1.66 \pm 0.25$ & $1.5 \pm 0.27^{*}$ & $1.47 \pm 0.27^{*}$ \\
\hline$\overline{\mathrm{BP}} \mathrm{mmHg}$ & $112 \pm 22$ & $109 \pm 20$ & $103 \pm 19$ & $97 \pm 19^{*}$ & $94 \pm 18^{*}$ \\
\hline Ao diast mml Ig & $95 \pm 20$ & $95 \pm 20$ & $85 \pm 21$ & $80 \pm 18^{*}$ & $75 \pm 18^{*}$ \\
\hline PCWPmmHg & $6.3 \pm 3$ & $5 \pm 3$ & $6 \pm 2.5$ & $5.5 \pm 2.6$ & $5.6 \pm 2.5$ \\
\hline$\overline{\mathbf{P A}} \mathrm{mm} \mathbf{H g}$ & $12 \pm 4$ & $11.5 \pm 4$ & $11.0 \pm 3$ & $10 \pm 3.5$ & $11.0 \pm 3.5$ \\
\hline $\mathrm{SVml}$ & $16 \pm 5$ & $16 \pm 4$ & $16 \pm 5$ & $17 \pm 5$ & $17 \pm 5$ \\
\hline Peak L VdP/dt mmHg $\sec ^{-1}$ & $2000+654$ & $1883 \pm 595$ & $1687 \pm 565$ & $1529 \pm 498^{*}$ & $1329 \pm 430^{*}$ \\
\hline SVR dyne-sec $\mathrm{cm}^{-5}$ & $3880 \pm 1840$ & $3914 \pm 1892$ & $4033 \pm 193]$ & $4211 \pm 2011$ & $4299 \pm 2023$ \\
\hline PVR dyne $\cdot \mathrm{sec} \cdot \mathrm{cm}^{-5}$ & $230 \pm 43$ & $239 \pm 44$ & $242 \pm 45$ & $236 \pm 43$ & $220 \pm 41$ \\
\hline
\end{tabular}

${ }^{*} p<0.05$ when compared with control value. 
haemodynamic parameters whose changes reached statistical significance $(\mathrm{p}<0.05)$ were $\mathrm{HR}, \mathrm{CO}, \mathrm{LV}$ and peak $L V$ dP/dt in periods $P_{4}$ and $P_{5}$, when compared with $P_{1}$ within the clonidine group (Group II). The largest reduction of $\mathrm{HR}, \mathrm{CO}, \mathrm{LV}$ and peak $\mathrm{LV} \mathrm{dP} / \mathrm{dt}$ were observed in $\mathrm{P}_{5}$ and were respectively $25,21,20$ and 30 per cent of control values $(p<0.05)$. Stroke volume was maintained. No changes in SVR nor PVR were observed. The injection of clonidine by $3 \mu \mathrm{g} \cdot \mathrm{kg}^{-1}$ increments did not result in any transient increase in $\mathrm{BP}$ or $\mathrm{HR}$. No significant changes of measured and calculated parameters were observed in the control group (Group II) during the study period.

\section{Discussion}

Epidural administration of clonidine resulted in a signifcant and sustained reduction of BP, HR, LV, CO and peak $\mathrm{LV} \mathrm{dP} / \mathrm{dt}$ only after a total cumulative dose of $9 \mu \mathrm{g} \cdot \mathrm{kg}^{-1}$. BP fell 15 per cent and HR was reduced 25 per cent from control values $(p<0.05)$. These changes are comparable in magnitude to those observed by Yasuoka and Yaksh ${ }^{9}$ after intrathecal administration of $5 \mu \mathrm{g}$ of clonidine in unanaesthetized rats. Intrathecal clonidine, however, in the dose range employed during this investigation ( 3 to $8 \mu \mathrm{g} \cdot \mathrm{kg}^{-1}$ ) resulted in marked reduction of BP and $\mathrm{HR}$, approximately 33 per cent of control values, in anaesthetized rats; ${ }^{8}$ yet larger doses $\left(30-80 \mu \mathrm{g} \mathrm{kg}^{-1}\right)$ produced a predominant pressor effect, likely because of systemic absorption. ${ }^{9}$ At variance with the present results, chronic epidural infusion of very large doses of clonidine ( 100 to $600 \mu \mathrm{g} \cdot \mathrm{kg}^{-1}$-day ${ }^{-1}$ ) in unanaesthetized sheep has been reported to have no significant haemodynamic effects. The epidural route of administration appears therefore to produce a lesser haemodynamic impact as compared to intrathecal administration, despite doses of similar or greater magnitude, likely because of minimal systemic absorption and/or rostral spread of clonidine towards the brain stem. Further, the contribution of a reduced background sympathetic activity and the depression of the baroreflex mechanism ${ }^{12}$ resulting from halothane anaesthesia may explain the difference in the haemodynamic response to epidural clonidine observed in the present study when compared to studies in the awake animuls reported by Coombs. ${ }^{10}$

In tetraplegic patients where there is no significant peripheral sympathetic tone, and where the baroreflex arch is interrupted, clonidine does not affect mean resting systolic and diastolic bloud pressures or reduce plasma norepinephrine. ${ }^{13}$ This suggests that descending influences from the brain stem, determining peripheral sympathetic outflow, are of primary importance for the hypotensive effect of clonidine in the resting state.

By contrast its analgesic effects may occur predomi- nantly at the spinal level and are due to depression of synaptic efficacy in spinal nociceptive pathways. ${ }^{5}$ Halothane anaesthesia, therefore, may potentiate the haemodynamic response to clonidine in view of inhibition of the baroreflex response and reduction of the background sympathetic activity. It is conceivable then that the haemodynamic consequences of epidural clonidine would be less pronounced in nonanaesthetized humans, as the results obtained in awake sheep suggests. ${ }^{10}$ While the reduction of $\mathrm{BP}$ is of central origin and due to inhibitions of the tonic vasomotor centre located in the lower brain stem, clonidine has effects occurring independently of the supraspinal cerebral structures.

Neurons involved in tonic and reflex control of $\mathrm{BP}^{14}$ project to the intermediolateral column of the spinal cord. ${ }^{15}$ In this region, which contains the cell bodies of the sympathetic preganglionic neurons that innervate directly the adrenal medulla and the sympathetic ganglia, a very dense noradrenergic innervation and alpha $a_{2}$-adrenoceptor binding sites have been identified. ${ }^{16}$ Activation of presynaptic alpha $a_{2}$-adrenoceptors reduces transmitter release (dependent on intensity of stimulation) in response to neuronal activity; ${ }^{17}$ this results in reduction of sympathetic outflow ${ }^{18}$ and of plasma norepinephrine. ${ }^{19}$ The extensive distribution of noradrenergic fibres and alpha $a_{2}$. adrenoceptors throughout specific sites of the spinal gray matter, i.e., intermediolateral column and dorsal horn neurons, suggests that descending noradrenergic systems have potentially important and widespread connections with spinal neurons involved in regulating autonomic and sensory activity.

The slowing of the heart rate produced by clonidine is thought to result both from a reduction of sympathetic drive and a simultaneous increase in parasympathetic tone. While the reduction of the sympathetic drive is of central and peripheral origin, the increase in vagal tone is due to a central mechanism which involves the reduction of tonic sympathetic influences on the excitatory cardiovascular neurons, and occurs only in presence of intact vagal pathways. ${ }^{20}$ Therefore, the most likely mechanisms involved in the slowing of the heart rate after epidural clonidine are the decrease of the firing rate of preganglionic sympathetic neurons located in the intermediolateral column of the spinal cord and of the neurons in the medulla involved in the cardiovascular control and the increased vagal tone, particularly at the highest doses Inhibition of the postganglionic sympathetic nerves which requires rather high doses: ${ }^{17}$ however, may also have played a role.

The gradual reduction of sympathetic outflow to the heart, rather than a direct effect, explains the reduction of myocardial contractility as indicated by the reduction of peak LV dP/dt. Indeed, clonidine does not have intrinsic 
negative inotropic effects on isolated papillary muscle ${ }^{21}$ and in heart-lung preparations. ${ }^{22}$ In addition to the reduction of sumpathetic tone, other factors have to be considered in explaining the depression of peak $L V \mathrm{dP} / \mathrm{dt}$ observed. While the instantaneous rate of change of ventricular pressure, prior to the opening of the aortic valve, is closely related to the rate of change of wall tension and reflects changes in contractility, changes in fibre length or preload, mean and diastolic aortic pressures and heart rate modify this isovolemic index of contractility. ${ }^{23}$ In the present study preload, as indicated by left ventricular end-diastolic pressure (LVEDP) did not change significantly; however, HR, mean and diastolic aortic pressures were significantly reduced, therefore contributing to the depression of $\mathrm{LV} \mathrm{dP} / \mathrm{dt}$.

Cardiac output was significantly reduced by the highest dose of clonidine administered (Table). The cause of reduction of $\mathrm{CO}$ has been previously reported to be the result of multiple factors such as increased vagal activity and loss of sympathetic tone resulting in reduced ventricular performance, ${ }^{24}$ and reduction of venous retum. ${ }^{25}$

Increased vagal tone may be an important cause of the fall in CO produced by clonidine, especially when heart rate is reduced to frequencies where $\mathrm{CO}$ is strongly dependent on HR. However, because of the range of $\mathbf{H R}$ observed this is unlikely to have played a major role.

Stroke volume increased slightly and LVEDP did not change significantly, therefore the end systolic volume at a slightly reduced end-systolic pressure either did not change or was slightly reduced. Depression of systolic ventricular performance is thus not explained by an increased end systolic pressure-volume ratio (a sensitive indicator of ventricular contractility) ${ }^{26}$ and therefore by the reduction of the extent of ventricular shortening, but rather by the reduction of the mean ejection rate as recently reported. ${ }^{27}$

In addition to the reduction of $\mathrm{LV}$ pump performance discussed, the reduction of $\mathrm{CO}$ observed with clonidine may be due to a reduction of venous return. The loss of sympathetic tone to the great veins would result in a dilatation of the capacitance vessels, thereby reducing the driving pressure for venous return or mean systemic pressure.

In support of this explanation, clonidine produced reduction of venous return by increasing the volume of capacitance vessels in dogs on cardiopulmonary bypass; ${ }^{25}$ this would account for the reduction of LVEDP observed. However, the small changes in preload, despite dilation of capacitance vessels suggest that reduction of alpha sympathetic tone may result in diminished resistance to venous return, therefore reducing the impact of capacitance vessels dilation on venous return and $\mathrm{CO}$.

In summary, changes in autonomic tone, particularly the reduction of sympathetic tone with its repercussions on ventricular pumping performance, cardiac frequency and venous return could explain the reduction of $\mathrm{CO}$ observed. No changes in SVR occurred, therefore the reduction on $\mathrm{BP}$ is thus explained by the reduction in flow. A reduction of total resistance would have been expected in view of the reduction of the sympathetic tone; however, the passive stretching of the vessel wall by the ejected blood was likely reduced, and resulted in no net change. ${ }^{29}$

Clonidine has been shown to have potent analgesic properties both in experimental animals and humans. . $^{2,3}$ The spinal sitc of the analgesic effect ${ }^{5}$ associated with the lack of respiratory depression ${ }^{29}$ and of neurotoxicity, ${ }^{10}$ the minimal haemodynamic changes observed in the anaesthetized dog in the present study, and in the awake ${ }^{10}$ sheep, despite the high dose given, point out the safety of the epidural route of administration of clonidine. If these experimental observations can be extrapolated to clinical situations, the results of this study suggest that epidural clonidine may be clinically useful in the management of acute postoperative pain, or as an adjunct to local anaesthetic for epidural anaesthesia.

\section{References}

1 Pettinger WA. Pharmacology of clonidine. J Cardiovasc Pharmacol 1980; 12: (Suppl.) 2l-8.

2 Spaulding TC, Fielding S, Venafro JJ, Lal $H$, Antinociceptive activity of clonidine and its potentiation of morphine analgesia. Eur J Pharmacol 1979; 58: 19-25.

3 Tamsen A, Gordh $T$. Epidural clonidinc produces analgesiu. Lancel 1984; 2: 231-2.

4 Coombs DW. Saunders $R L$, Lachance D, Savage $S$, Regnarsson TS. Jensen LE. Intrathecal morphine tolerance: use of intrathecal clonidine, DADLE, and intraventricular morphine. Anesthesiology 1985; 62: 358-63.

5 Calvillo $O$, Ghignone $M$. Presynaptic effect of clonidine on unmyelinated afferent fibers in the spiral cord of the cat. Neurosci Lell 1986; 64: 335-9.

6 Reddy SVR, Yaksh TL. Spinal noradrenergic terminal system mediates antinociception. Brain Res 1980; 189 ; 391-401.

7 Svenson TH, Bunney BS, Aghajanian GK. Inhibition of both noradrenergic and serotonergic neurons in brain by the alpha-adrenergic agonist clonidine. Brain Res 1976; 92: 291-306.

8 Finch $L$, Hicks $P E$, Paley $H E$. Investigation into the role of spinal atpha-adrenoceptors in cardiovascular modulation in rats. Br J Pharmac 1980; 68: 185P-186P.

9 Yasuoka S, Yaksh TL. Effects on nociceptive threshold and blood pressure of intrathecally administered morphine and alpha-adrenergic agonists. Neuropharmacol 1983; 22: 309-15. 
10 Coombs DW, Allen C, Meier FA, Fratkin JD. Chronic intraspinal clonidine in sheep. Regional Anesthesia 1984; 9: 47-8.

11 Wallenstein S, Zteker CL, Fleiss JL. Some statistical methods useful in circulation research. Circ Res 1980; 47; 1-9.

12 Duke PC, Fownes D, WadeJ. Halothane depresses control of heart rate in man. Anesthesiology 1977; 46: 184-7.

13 Mathias CJ, Reid JL, Wing LMH, Frankel HL, Christensen NJ. Antihypertensive effects of clonidine in tetraplegic subjects devoid of central sympathetic control. Clin Sci 1979; 57: 425s-428s.

14 Reis DJ, Granata AR, Joh TH, Rass CA, Ruggiero DA, Park DH. Brain stem catacholamine mechanisms in tonic and reflex control of blood pressure. Hypertension 1984; 6 (Supp1. 11): II-7-II-15.

15 Ross CA, Armstrong DM, Ruggiero DA, Pickel VM, Joh TH. Reis DJ. Adrenaline neurons in the rostral ventrolateral medulla innervate thoracic spinal cord: a combined immunocytochemical and retrograde transport demonstration. Neurosei Lett 1981; 25: 257-62.

16 Unnerstall JR, Kopajtic TA, Kuhar MJ. Distribution of alphaz-agonist binding sites in the rat and human central nervous system: analysis of some functional, anatomic correlates of the pharmacologic effects of clonidine and related adrenergic agents. Brain Res Rey 1984; 7: 69-101.

17 Langer SZ, Hicks PE. Physiology of the sympathetic nerve ending. $\mathrm{Br} J$ Anaesth 1984; 56: 689-700.

18 Guyenet $P G$, Cabot $J B$. Inhibition of sympathetic preganglionic neurons by catecholamines and clonidine: mediation by an alpha-adrenergic receptor. J Neurosci 1987; 1: 908-17.

19 Veith RC, Best JD. Haller JB. Dose dependent suppression of norepinephrine appearance rate in plasma by clonidine in man. J Clin Endocrinol Metab 1984; 59: $151-4$.

20 Cavero 1, Roach $A G$. Effects of clonidine on canine cardiac neuroeffector structures controlling heart rate. $\mathrm{Br}$ J Pharmac 1980; 70: 269-76

21 Motz W, Ippisch $R$, Strauer BE. The role of clonidine in hypertensive disease. Chest 1983; 2 (Suppl.) : 433-5.

22 Hoefke $W$, Koebinger $W$. Pharmakologische witkungen des 2(2,6-Dichlorophenylamino)-2 Imidazolin-hydrochlorids, einer neuen antihypertensiven Substanz. Arzneimittel-Forsch 1966; 16: 1038-56.

23 Wallace AG, Skinner NS Jr, Mischell JH. Hemodynamic determinants of maximal rate or rise of left ventricular pressure. Am J Physiol 1963; 205: 30-6.

24 Laubie M, Schmitt $H$. Influence of autonomic blockade on the reduction in myocardial performance produced by clonidine. Eur J Pharmacol 1974; 25: 56-65

25 Nayler WG, Price JM, Swann JB, MCInes I, Race D, Lowet $E$. Effect of bypotensive drug St 155 (Catapress) on the heart and peripheral circulation. J Pharmacol Exp Ther 1968; 164: 45-59.

26 Sagawa $K$. The ventricular pressure volume diagram revisited. Circ Res 1978; 43: 677-87.

27 Timisjarvi J, Jarvensivu P, Kettunen $R$. Left ventricular response to intravenous adminjstration of clonidine in anesthetized dogs. Acta Physiol Scand Suppl 1984; 164: 45-59.

28 Folkow $B$, Karlsırom $G$, Nilsson $H$, Sjoblom $N$. How do changes in diameter at the precapillary level affect cardiovascular function? J Cardiovase Pharmacol 1984; 6: 280-8.

29 Marwell $G M$. The effects of 2-(2,6-dichlorophenylamino)2 -imidazoline hydrochloride (Catapres ${ }^{6}$ ) upon the systemic and coronary hemodynamics and metabolism of intact dogs. Arch Int Pharmacodyn Therap 1969; 181: 7-14.

\section{Résumé}

Les effets hémodynamiques de l'administration de clonidine dans l'espace épidural étaient étudiés chez 16 chiens anesthesiés à l'halothane. Les animaux étaient divisés en deux groupes d'une façon randomisée: le groupe la reçu trois doses de $3 \mathrm{ml}$ de physiologique, le groupe $l l$ a reçu irois doses de $3 \mu \mathrm{g} \cdot \mathrm{kg}^{-1}$ de clonidine, à travers un cathester ëpidural dont le bout distal élait localisé entre $L_{2}$ et $T_{11}$. Les mesures hémo. dynamiques de contrôle étaient prises une heure après l'accomplissement de la prêparation chirurgicale (période $P_{1}$ ); elles étaient répérées r.haque 45 minutes après chaque dose de rajout (période $P_{2}, P_{3}, P_{4}$ ) et 105 minutes après avoir atteint une dose cumularive totale de $9 \mu \mathrm{g} \cdot \mathrm{kg}^{-1}$ de clomidine ou $9 \mathrm{ml}$ de salin (période $P_{5}$ ). Aucun changement significatif à travers le temps $n^{\prime}$ a été abservé dans le groupe I. Dans le groupe II la clonidine a produit une diminution statistiquement significative de la pension artérielle systémique (BP), de la pression du ventricule gauche $(L V)$, de la frequence cardiaque $(H R)$, du débit cardiaque $(C O)$ at $d P / d t$ maximal uniquement après avoir atteint la dose maximale totale de $9 \mu \mathrm{g} \cdot \mathrm{kg}^{-1}$. La BP a diminué de 15 pour cent, $\mathrm{CO}$ de 21 pour cent, $H R$ de 25 pour cent, LV de 20 pour cent et le dP/dt de 30 pour cent quand les mesures faites au temps $P_{5}$ étaient comparées aur valeurs de contrôle dans le groupe $H(p<0.05)$. Ces effets hémodynamiques de la clonidirte sant probablement dus à une absorption systémique minime etiou a une diffusion vers le haut du médicament vers son site d'action dans le cerveau. La diminution de la fréquence cordiaque, débit cardiaque et la tension anérielle ainsi que les indices isovolumiques de contractilité sont probablement expliqués par une réduction de la réponse sympathique de la moëlle épinière er du bulbe rachidien ainsi qu' une augmentation du tonus parasympathique.

Si on pouvail extrapoler ces observations expérimentales aux conditions cliniques et parce que les effets hémodynamiques ont été observés uniquement avec des fortes doses de clonidine qui est un puissant analgésique, l'administration épidurale de ceite drogue apparait sécuritaire et pourrait être utile au poins de vue thérapeutique contre les douleurs aigues postopératoires. 